\title{
PENGARUH STORE LAYOUT, INTERIOR DISPLAY, HUMAN VARIABLE TERHADAP CUSTOMER SHOPPING ORIENTATION DI RESTORAN DEWANDARU SURABAYA
}

\author{
Fransisca Andreani, Monika Kristanti, Adiguna Yapola \\ Faculty of Economics, Petra Christian University, Surabaya, Indonesia \\ Email: andrea@peter.petra.ac.id; mkrist@peter.petra.ac.id
}

\begin{abstract}
Abstrak
Penelitian ini bertujuan untuk mengetahui pengaruh store layout, interior display, human variable terhadap customer shopping orientation pada restoran Dewandaru Surabaya. Analisis kausalitas digunakan dengan teknik judgement sampling yang melibatkan 150 sampel. Analisis regresi digunakan untuk mengolah data. Hasil penelitian menunjukkan bahwa store layout, interior display, human variable berpengaruh secara serempak dan parsial terhadap customer shopping orientation pada restoran Dewandaru Surabaya. Di antara ketiga variabel tersebut, store layout merupakan variabel yang paling dominan mempengaruhi customer shopping orientation restoran Dewandaru Surabaya.
\end{abstract}

Kata kunci: Store Layout, Interior Display, Human Variable, Customer Shopping Orientation.

\begin{abstract}
This study is to determine the effects of store layout, interior displays, human variable toward customer shopping orientation in Dewandaru Restaurant Surabaya. It is a causal analysis using judgement sampling with 150 samples. Regression analysis is used to find to show that store layout, interior display, human variable infuence customer shopping orientation simultaneously and partially in Dewandaru Restaurant Surabaya. Among these three variables, store layout is the most dominant variable that influences customer shopping orientation in Dewandaru Restaurant Surabaya.
\end{abstract}

Keywords: Store Layout, Interior Display, Human Variable, Customer Shopping Orientation.

\section{PENDAHULUAN}

Pertumbuhan bisnis makanan dan minuman masih tercatat sebagai pertumbuhan yang tinggi di berbagai belahan dunia (Nonto, 2006). Berbagai outlet yang menawarkan produk makanan dan minuman dalam berbagai bentuk banyak bermunculan, dari yang sederhana hingga yang mewah. Hal ini disebabkan karena makanan adalah salah satu kebutuhan pokok yang harus dipenuhi manusia. Hasil penelitian mengungkapkan bahwa alasan rasional outlet makanan tumbuh karena para pebisnis makanan bisa mengantongi keuntungan bersih minimal 50\% setelah dikurangi biaya operasional (Sari, 2005).

Pertumbuhan pesat di industri makanan, khususnya restoran membuat pebisnis sadar akan posisi persaingan industri sehingga mereka harus mempertahankan keunggulan bersaing. Hal ini sangat penting bagi suatu usaha dalam mempertahankan pelanggan dan keberadaannya di industri makanan.
Keunggulan bersaing ini bisa menjadi faktor yang membedakannya dengan pesaing.

Diferensiasi dan usaha pemasaran yang inovatif dapat digunakan untuk meningkatkan keunggulan bersaing. Salah satu usaha pemasaran yang inovatif adalah kreativitas dalam menciptakan suasana/ lingkungan restoran yang unik. Ini sangat penting mengingat dewasa ini seseorang berbelanja bukan hanya sebagai kegiatan fungsional untuk membeli barang atau jasa, tapi merupakan kegiatan untuk mengisi waktu, rekreasi, hiburan atau bahkan untuk melepas stress (Ma'ruf, 2006). Selain store layout dan interior display faktor lain yang ikut dipertimbangkan pelanggan adalah human variable (Turley \& Milliman, 2000).

Restoran Dewandaru di jalan Mayjen Sungkono, Surabaya merupakan salah satu dari sekian banyak restoran yang memiliki citra yang unik. Citra ini disampaikan melalui store layout yang menarik, desain interiornya yang unik dengan menggunakan benda-benda bernuansa budaya tradisional yang 
memiliki nilai historis di dalamnya. Selain itu restoran ini juga mengutamakan penampilan karyawan dan tingkat kepadatan pelanggan maupun karyawan (human variable) yang berbeda dari restoran lainnya. Diferensiasi ini diharapkan mampu mempengaruhi orientasi membeli pelanggannya.

Orientasi membeli pelanggan (customer shopping orientation) merupakan ketertarikan perhatian pelanggan dalam berbelanja pada kategori produk tertentu. Customer shopping orientation digunakan untuk meramalkan variabel tingkah laku yang berhubungan dengan produk, seperti keterlibatan produk, perilaku pembelian, dan karakteristik pelanggan. Untuk memperoleh data mengenai customer shopping orientation dilakukan wawancara terhadap 30 responden pada bulan November 2011. Hasilnya menunjukkan bahwa responden yang membeli karena layout sebanyak 12 orang, 8 pelanggan membeli karena pelayanan karyawan, 6 pelanggan membeli karena penampilan interior restoran dan 4 pelanggan membeli karena citra perusahaan. Berdasarkan fenomena ini, peneliti tertarik untuk melihat dan menganalisis store layout, interior display dan human variable yang mempengaruhi customer shopping orientation pada restoran Dewandaru di Surabaya.

Berdasarkan latar belakang di atas dapat dirumuskan permasalahan sebagai berikut, yaitu: Apakah store layout, interior display dan human variable berpengaruh secara serempak dan signifikan terhadap customer shopping orientation pada restoran Dewandaru di Surabaya? Apakah store layout, interior display dan human variable berpengaruh secara parsial dan signifikan terhadap customer shopping orientation pada restoran Dewandaru di Surabaya? Diantara variabel store layout, interior display dan human variable manakah yang berpengaruh dominan terhadap customer shopping orientation pada restoran Dewandaru di Surabaya?

\section{LANDASAN TEORI DAN HIPOTESIS}

Store layout merujuk pada perlengkapan, alokasi ruang, pengelompokan produk, arus lalu lintas, departemen lokasi, dan alokasi dalam departemen (Turley \& Milliman, 2000). Pebisnis yang hendak menata sebuah store harus memperhatikan tujuan yang ingin dicapai. Menurut Levy dan Weitz (2001) ada 3 hal yang harus diperhatikan dalam menentukan suasana lingkungan store, yaitu:

1. Suasana lingkungan store harus konsisten dengan citra store dan strategi secara keseluruhan.

2. Menentukan pelanggan dalam pengambilan keputusan pembelian.
3. Biaya yang diperlukan agar sesuai dengan yang dianggarkan.

Store layout dapat mempengaruhi keadaan emosi pelanggan. Keadaan emosi pelanggan terdiri perasaan senang dan perasaan yang dapat membangkitkan keinginan, baik yang muncul secara psikologis ataupun keinginan yang bersifat mendadak (impulsif) untuk melakukan pembelian. Turley dan Milliman (2000) menyatakan bahwa untuk mengukur store layout digunakan indikator sebagai berikut:

a. Alokasi luas ruangan yang sesuai

b. Penempatan meja/kursi yang sesuai

c. Lokasi penempatan ruangan yang baik

Display merupakan salah satu dari alat promosi penjualan yang mempunyai fungsi untuk menarik perhatian pelanggan agar dapat melakukan pembelian. Interior display meliputi display produk, poster, tanda-tanda, kartu, teleteks pesan, dan hiasan dinding yang ditata sedemikian rupa dan berhubungan dengan efek ruang pajang. Istilah "ruang pajang" digunakan untuk menggambarkan besarnya ruang yang dialokasikan untuk suatu produk, efek dari lokasi rak, atau efektivitas suatu tampilan produk sehingga efek dari rak, besar ruang dan lokasi penjualan saling berkaitan atau ada hubungan positif antara ruang pajang dan unit penjualan (Turley \& Milliman, 2000).

Lebih lanjut Turley dan Milliman (2000) menyatakan bahwa interior display yang baik secara signifikan dapat memiliki efek pada pelanggan untuk melakukan pembelian. Hal ini dapat terjadi baik ketika kualitas produk setara dengan pesaing. Bahkan ketika kualitas produk tidak setara dengan pesaing, interior display yang baik dan lengkap juga dapat mempengaruhi pelanggan. Hal ini senada dengan pendapat Ma'ruf (2006) bahwa keinginan untuk melakukan pembelian dapat diciptakan melalui interior display yang menarik.

Untuk mengukur interior display digunakan indikator sebagai berikut (Turley \& Milliman, 2000):

a. Perabotan yang menarik

b. Papan tanda yang menarik

c. Dekorasi dinding yang menarik

Human variable merujuk pada kerumunan atau kepadatan pelanggan, privasi, karakteristik pelanggan, personil/karyawan karakteristik, dan seragam karyawan. Tingkat kepadatan pelanggan dan karyawan dalam suatu tempat dapat mempengaruhi orientasi pembelian dan kepuasan pelanggan. Dalam penelitian yang dilakukan Bateson dan Hui (Turley \& Milliman, 2000) terungkap bahwa beberapa pelanggan tidak menyukai dampak modulasi lingkungan negatif yang 
terkait dengan kepadatan pelanggan (misalnya kondisi restoran terlalu ramai pengunjung dan sangat padat). Lebih lanjut juga menemukan bahwa strategi adaptasi pelanggan pada tingkat kepadatan di suatu tempat berpengaruh tinggi pada kepuasan belanja (Turley \& Milliman, 2000)

Menurut Turley dan Milliman (2000), human variable dapat menggunakan indikator sebagai berikut:

a. Karakteristik pelanggan yang baik.

b. Karakteristik karyawan yang baik

c. Pakaian karyawan yang rapi.

Bagi pelanggan berbelanja akan menyenangkan jika pebisnis memberikan kesan yang baik, keputusan pelanggan untuk masuk atau tidak pada outlet tersebut berdasarkan persepsi yang diperoleh dari penglihatannya. Sifat rasional yang kuat akan menyebabkan pelanggan berorientasi dengan tujuan belanja yaitu mencari barang yang dibutuhkan atau diinginkan sehingga aspek fungsional pusat perbelanjaan lebih diutamakan daripada suasana yang memikat hati. Sebaliknya pelanggan yang berorientasi "rekreasi" akan mencari pusat perbelanjaan yang menyenangkan/nyaman, pelanggan akan beranggapan bahwa belanja akan lebih baik jika dalam suasana yang menyenangkan (Ma'ruf, 2006).
Orientasi belanja pelanggan (customer shopping orientation) yang lebih mementingkan hal-hal yang fungsional akan memilih pusat perbelanjaan dengan beberapa pertimbangan baik dari lokasi yang mudah dicapai, memiliki lokasi parkir yang strategis, barang yang dicari tersedia dengan lengkap, harga yang ditawarkan menarik, dan sebagainya. Menurut Ma'ruf (2006), orientasi belanja pelanggan yang berorientasi pada "rekreasi" lebih cenderung memilih pusat perbelanjaan yang bergengsi, pilihan produk yang dijual banyak, suasana di outlet nyaman, memiliki visual merchandising, fasilitas di dalam outlet, fasilitas kredit, dan sebagainya.

Turley dan Milliman (2000) menyatakan bahwa untuk mengukur customer shopping orientation dapat digunakan indikator sebagai berikut:

a. Pelanggan membeli di store yang didasarkan pada gengsi.

b. Pelanggan membeli di store yang dianggap memiliki pengetahuan dan pengalaman tentang produk yang bermerek.

c. Pelanggan membeli di store yang mementingkan kenyamanan.

Turley dan Milliman (2000) menyatakan bahwa orientasi pelanggan berbelanja dipengaruhi store layout, interior display, dan human variable.

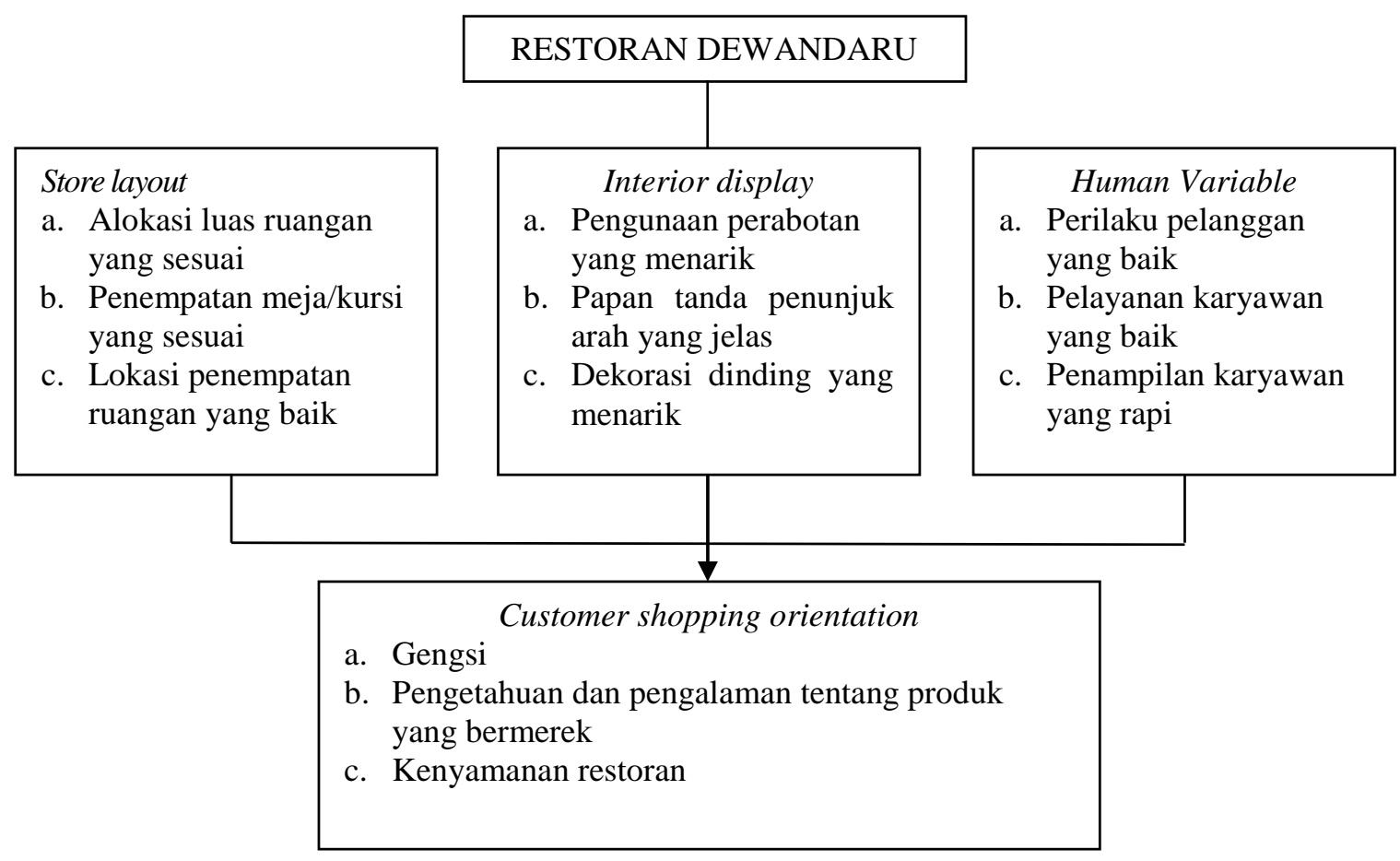

Gambar 1. Kerangka Berpikir

Sumber: Turley \& Milliman (2000) 
Maka hipotesis dari penelitian ini adalah: Store layout, interior display dan human variable berpengaruh secara serempak dan signifikan terhadap customer shopping orientation pada restoran Dewandaru di Surabaya. Store layout, interior display dan human variable berpengaruh secara parsial dan signifikan terhadap customer shopping orientation pada restoran Dewandaru di Surabaya. Di antara ketiga variabel yang ada, store layout berpengaruh paling dominan terhadap customer shopping orientation pada restoran Dewandaru di Surabaya.

Hal ini didasarkan atas pra survey terhadap pelanggan restoran Dewandaru yang mana kebanyakkan pelanggan melakukan pembelian karena store layout.

\section{METODE PENELITIAN}

Penelitian ini adalah penelitian kausalitas yang menunjukkan arah hubungan antara variabel bebas dengan variabel terikat, di samping mengukur kekuatan hubungan. Populasi dalam penelitian ini adalah pelanggan restoran Dewandaru di Surabaya.

Teknik sampling yang digunakan adalah non probability sampling. Jenis metode yang digunakan adalah judgement sampling dengan pemilihan sampel berdasarkan kriteria tertentu yaitu pernah makan di restoran Dewandaru Surabaya minimal sekali dan berusia minimal 17 tahun. Menurut Sugiyono (2007), penelitian dengan analisis multivariate menggunakan jumlah sampel minimal sebanyak 10 kali dari jumlah variabel yang diteliti. Oleh karena itu responden yang diambil sebanyak 150 orang karena semakin besar jumlah sampel semakin mewakili hasil penelitian.

Sumber data dalam penelitian ini merupakan data primer dan data sekunder. Data primer yaitu data yang diperoleh secara langsung dari responden melalui penyebaran kuesioner pada bulan Desember 2011. Data sekunder yaitu data penelitian yang diperoleh secara tidak langsung melalui media perantara (internet dan jurnal).

Variabel yang digunakan dalam penelitian ini terdiri dari 4 variabel. Variabel tersebut adalah:

1. Store layout $\left(\mathrm{X}_{1}\right)$ merupakan persepsi pelanggan pada layout/penataan barang di restoran Dewandaru yang diukur dengan 3 indikator yaitu (Turley \& Milliman, 2000):

a. Restoran Dewandaru memiliki alokasi luas ruangan yang nyaman bagi kebutuhan pelanggan;

b. Penataan serta penampilan meja/kursi yang dilakukan restoran Dewandaru bersih dan rapi

c. Lokasi penempatan fasilitas-fasilitas umum tidak menganggu kenyamanan pelanggan;
2. Interior display $\left(\mathrm{X}_{2}\right)$ merupakan persepsi pelanggan pada penataan interior di restoran Dewandaru yang diukur dengan 3 indikator yaitu (Turley \& Milliman, 2000):

a. Perabotan yang digunakan di restoran Dewandaru unik dan menarik

b. Papan nama restoran Dewandaru menarik

c. Dekorasi ruangan serta dinding restoran Dewandaru menarik.

3. Human variable $\left(\mathrm{X}_{3}\right)$ merupakan persepsi pelanggan pada karakteristik pelanggan dan karyawan di restoran Dewandaru yang diukur dengan 3 indikator yaitu (Turley \& Milliman, 2000):

a. Perilaku sesama pelanggan restoran Dewandaru tidak menganggu kenyamanan pelanggan lainnya.

b. Pelayanan karyawan restoran Dewandaru ramah

c. Penampilan karyawan restoran Dewandaru rapi.

4. Consumer shopping orientation $\left(\mathrm{Y}_{1}\right)$ merupakan orientasi pelanggan dalam berbelanja di restoran Dewandaru yang diukur dengan 3 indikator yaitu (Turley \& Milliman, 2000):

a. Pelanggan makan di restoran Dewandaru didasarkan pada gengsi.

b. Pelanggan makan di restoran Dewandaru memiliki pengetahuan dan pengalaman tentang produk yang bermerek.

c. Pelanggan makan di restoran Dewandaru mementingkan kenyamanan dalam membeli makanan.

Sebelum data diolah maka dilakukan beberapa uji berikut ini:

1. Uji Validitas

Uji validitas digunakan untuk mengukur sah atau valid tidaknya suatu kuesioner. Suatu kuesioner dikatakan valid apabila hasil dari korelasi tersebut mempunyai tingkat signifikansi $0,05(5 \%)$ atau kurang (Ghozali, 2005).

2. Uji Reliabilitas

Suatu kuesioner dikatakan reliabel atau handal jika jawaban seseorang terhadap pernyataan adalah konsisten atau stabil dari waktu ke waktu. Jika koefisien Cronbach's Alpha lebih dari 0,6 maka instrumen dikatakan reliabel Ghozali (2005).

3. Uji Asumsi Klasik

Uji ini dimaksudkan untuk mengetahui apakah penggunaan model regresi linier berganda dalam analisis data telah memenuhi asumsi klasik.

a. Multikolinieritas

Uji multikolinearitas bertujuan untuk menguji apakah dalam model regresi ditemukan adanya 
korelasi antar variabel bebas. Model regresi yang baik seharusnya tidak terjadi korelasi diantara variabel bebas. Multikolineritas dapat dilihat dari nilai tolerance dan Variance Inflation Factor (VIF). Nilai cutoff yang umum dipakai untuk menunjukkan adalah multikolineritas adalah nilai tolerance $<0.1$ atau sama dengan nilai VIF $>10$ (Ghozali, 2005).

b. Heteroskedastisitas

Ghozali (2005) menyatakan untuk mendeteksi ada atau tidaknya heterokesdastis dapat dengan melihat grafik plot antara nilai prediksi variabel terikat yaitu ZPRED dengan residualnya SRESID. Deteksi ada tidaknya heteroskedastisitas dapat dilakukan dengan melihat ada tidaknya pola tertentu pada grafik scatterplot antara SRESID dan ZPRED.

c. Autokorelasi

Untuk mendeteksi ada atau tidaknya autokorelasi ini dapat dilakukan dengan menggunakan pengujian Durbin-Watson (DW). Secara umum sebagai patokan adalah jika angka D-W diantara -2 sampai +2 , berarti tidak ada autokorelasi. Tanda "+" berarti ada autokorelasi positif, dan tanda "." berarti ada autokorelasi negatif.

Teknik analisis dalam peneltian ini adalah analisis regresi linier berganda yang digunakan untuk mengetahui besarnya pengaruh antara variabel bebas terhadap variabel tidak bebas. Model analisis regresi menurut Ghozali (2005) :

$$
\mathrm{Y}=\mathrm{a}+\mathrm{b}_{1} \mathrm{X}_{1}+\mathrm{b}_{2} \mathrm{X}_{2}+\mathrm{b}_{3} \mathrm{X}_{3}
$$

Analisis koefisien korelasi berganda $(\mathrm{R})$ digunakan untuk mengukur keeratan hubungan antara variabel bebas $(\mathrm{X})$ secara serempak terhadap variabel terikat $(\mathrm{Y})$ dengan menggunakan program SPSS versi 15. Selain itu koefisien determinasi berganda $\left(R^{2}\right)$ digunakan untuk mengukur atau menafsirkan seberapa besar variabel bebas (X) mampu menunjukkan perubahan pada variabel terikat $(\mathrm{Y})$. ini

Untuk pengujian hipotesis digunakan uji berikut

1. Uji F

Uji $F$ digunakan untuk menguji pengaruh variabel-variabel bebas $\left(\mathrm{X}_{\mathrm{i}}\right)$ secara signifikan serempak terhadap variabel terikat $(\mathrm{Y})$ dengan kondisi $\mathrm{F}_{\text {hitung }}>\mathrm{F}_{\text {tabel. }}$

2. Ujit

Uji t digunakan untuk mengetahui apakah variabel bebas secara parsial berpengaruh positif terhadap variabel terikat $(\mathrm{Y})$ dengan kondisi $t_{\text {hitung }} \geq \mathrm{t}_{\text {tabel }}$.

\section{HASIL PENELITIAN DAN PEMBAHASAN}

Restoran Dewandaru yang berdiri pada pertengahan tahun 2009 terletak di jalan Mayjend Sungkono 17-19, Surabaya. Dewandaru merupakan restoran yang menerapkan konsep culture restaurant serta menjual makanan peranakan Tionghoa sebagai menunya. Makanan peranakan Tionghoa sendiri merupakan citarasa makanan Indonesia tempo dulu, yang memadukan masakan Indonesia dan Cina. Menu makanan dan minumannya diberi nama yang unik seperti "Dewa Udang Merogoh Sukma", ataupun "Tjap Jay Nyonya Soerbaia" disertai dengan kesegaran dari "Es Opera Nona Shanghai"

Suasana budaya yang kental akan terasa begitu memasuki restoran ini. Joglo, patung dewa-dewi, serta beragam koleksi benda seni yang bernilai historis tinggi akan menyambut kehadiran pengunjung. Semakin ke dalam, pengunjung akan semakin merasakan perpaduan budaya yang begitu menarik dengan adanya bangunan utama restoran yang menyerupai rumah adat Tionghoa pada abad 18 dengan penempatan taman terbuka di bagian belakang yang menambah kesan romantis serta nyaman.

Restoran Dewandaru membidik segmen kalangan menengah ke atas, dengan keluarga sebagai target pasarnya. Restoran ini banyak didatangi oleh pelanggan yang ingin menghabiskan waktu bersama keluarga maupun kerabat, ataupun untuk menjamu relasi yang datang.

Dari hasil uji validitas didapat hasil bahwa semua item pernyataan adalah valid dengan nilai signifikansi lebih kecil dari 0,05. Dari hasil uji reliabilitas juga menunjukkan bahwa semua item pernyataan adalah reliabel dengan koefisien Cronbach's Alpha lebih besar dari 0,6.

Hasil uji asumsi klasik menunjukkan nilai tolerance variabel bebas lebih dari 0.1 dan nilai VIF kurang dari 10 yang berarti tidak ada multikolineritas antar variabel bebas dalam model regresi. Hasil uji heteroskedastisitas seperti pada gambar berikut ini menunjukkan tidak adanya heteroskedastisitas.

Hasil uji autokorelasi menunjukkan bahwa nilai DW sebesar 1,627 > 1,61, maka dapat disimpulkan bahwa tidak terdapat autokorelasi.

Hasil analisis menunjukkan bahwa sebagian besar responden berjenis kelamin perempuan, berusia 17-25 tahun, bekerja sebagai wiraswasta. Kebanyakan mereka memiliki pendapatan Rp. 4.000.000,00 < Rp. $6.000 .000,00$ dan frekuensi berbelanja dalam 1 bulan sebanyak 1 kali.

Hasil analisis regresi linier berganda disajikan dengan persamaan seperti ini:

$$
Y=-0,295+0,415 X_{1}+0,284 X_{2}+0,355 X_{3}
$$




\section{Scatterplot}

Dependent Variable: customers shopping orientation

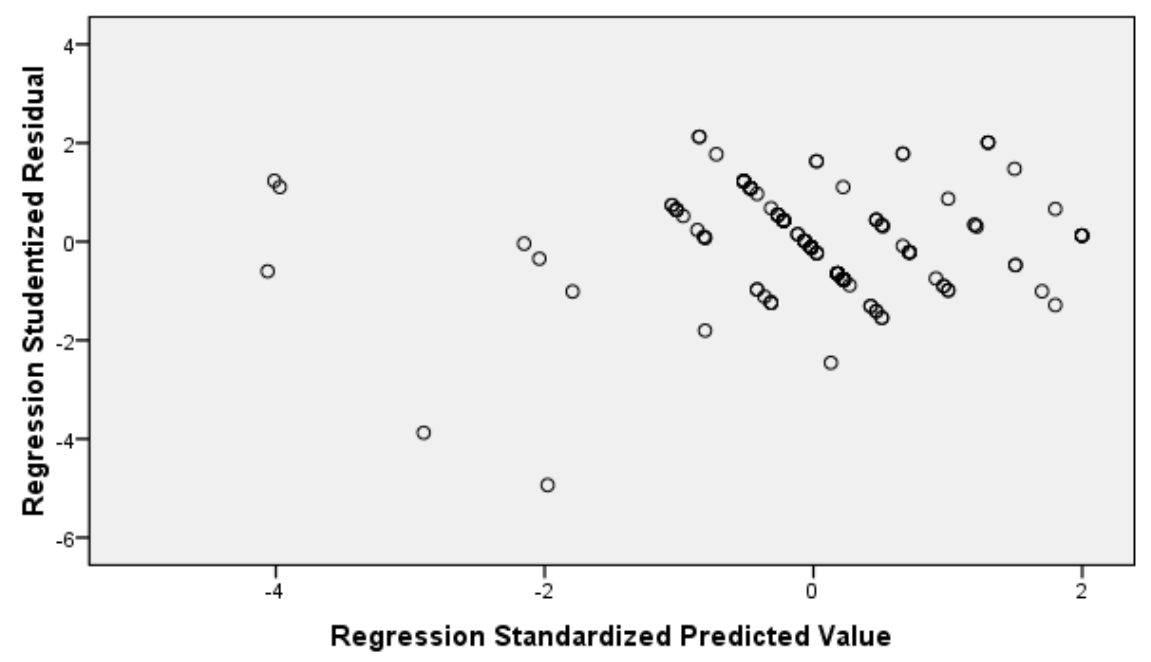

Gambar 2. Scatterplot

Tabel 1. Hasil Perhitungan Regresi Linier Berganda Variabel Bebas terhadap Variabel Terikat

\begin{tabular}{|c|c|c|c|c|}
\hline Variabel bebas & $\mathbf{B}$ & $\mathbf{t}_{\text {hitung }}$ & Sig. & $\mathbf{r}$ \\
\hline Konstanta & -.295 & -2.348 & .020 & \\
\hline $\mathrm{X}_{1}$ (store layout) & .415 & 9.325 & .000 & .611 \\
\hline $\mathrm{X}_{2}$ (interior display) & .284 & 5.944 & .000 & .441 \\
\hline $\mathrm{X}_{3}$ (human variable ) & .355 & 8.636 & .000 & .581 \\
\hline Variabel Terikat & \multicolumn{4}{|c|}{ Customer shopping orientation } \\
\hline F hitung $(3 / 146 ; 5 \%)$ & \multirow{2}{*}{\multicolumn{3}{|c|}{$\begin{array}{r}\text { Sig } \\
0.878\end{array}$}} & \\
\hline R Square & & & & \\
\hline $\mathrm{R}$ & \multicolumn{4}{|c|}{0,937} \\
\hline Adjusted R Square & \multicolumn{4}{|c|}{0,875} \\
\hline
\end{tabular}

Hasil analisis regresi linier berganda lengkapnya dapat dilihat pada Tabel 1. Bilangan konstan (B) sebesar $-0,295$ menunjukkan bahwa tanpa adanya pengaruh store layout $\left(\mathrm{X}_{1}\right)$, interior display $\left(\mathrm{X}_{2}\right)$ dan human variable $\left(\mathrm{X}_{3}\right)$, maka nilai customer shopping orientation $(\mathrm{Y})$ adalah negatif atau tidak ada orientasi pembelian pelanggan. Tetapi dengan adanya ketiga variabel $\mathrm{X}$ yang semua nilainya positif dan signifikansinya 0,000 , maka dapat dikatakan bahwa variabel $\mathrm{X}_{1}, \mathrm{X}_{2}$ dan $\mathrm{X} 3$ memberikan pengaruh terhadap customer shopping orientation sehingga terjadi pembelian.

Nilai $\mathrm{R}$ sebesar 0,937 menunjukkkan bahwa kemampuan store layout $\left(\mathrm{X}_{1}\right)$, interior display $\left(\mathrm{X}_{2}\right)$ dan human variable $\left(\mathrm{X}_{3}\right)$ dalam mempengaruhi customer shopping orientation $(\mathrm{Y})$ adalah sangat kuat karena nilainya mendekati 1 (satu). Koefisien determinasi berganda ( $R$ square) sebesar 0,878 menunjuk- kan bahwa pengaruh store layout $\left(\mathrm{X}_{1}\right)$, interior display $\left(\mathrm{X}_{2}\right)$ dan human variable $\left(\mathrm{X}_{3}\right)$ secara serempak terhadap customer shopping variable sebesar $87,8 \%$, sedangkan $12,2 \%$ sisanya dipengaruhi oleh faktor lain yang tidak diteliti. Hasil uji $\mathrm{F}$ dapat dilihat pada Tabel 2.

Karena $\mathrm{F}_{\text {hitung }}=349,405$ lebih besar dari $\mathrm{F}_{\text {tabel }}=$ 2,67 dan nilai signifikansinya adalah sebesar 0,000 sehingga model dikatakan layak dan bisa diterima. Oleh karena itu variabel store layout $\left(\mathrm{X}_{1}\right)$, interior display $\left(\mathrm{X}_{2}\right)$, dan human variable $\left(\mathrm{X}_{3}\right)$ berpengaruh secara serempak dan signifikan terhadap variabel customer shopping orientation (Y). Dengan demikian hipotesis pertama "store layout, interior display dan human orientation berpengaruh secara serempak dan signifikan terhadap customer shopping orientation pelanggan" dapat diterima. Hasil uji $t$ dapat dilihat pada Tabel 3. 
Tabel 2. Hasil Uji F

\begin{tabular}{ccccccc}
\hline & Model & Sum of Squares & df & Mean Square & F & Sig. \\
\hline 1 & Regression & 33,619 & 3 & 11,206 & 349,405 & 0.000 \\
& Residual & 4,683 & 146 & 0,032 & & \\
& Total & 38,301 & 149 & & & \\
& & & & & &
\end{tabular}

Tabel 3. Hasil Uji t

\begin{tabular}{|c|c|c|c|c|c|c|c|c|c|c|}
\hline \multirow{2}{*}{ Model } & \multicolumn{2}{|c|}{$\begin{array}{c}\text { Unstandardized } \\
\text { Coefficients }\end{array}$} & \multirow{2}{*}{$\begin{array}{c}\text { Standardized } \\
\text { Coefficients } \\
\text { Beta } \\
\end{array}$} & \multirow{2}{*}{$\mathbf{T}$} & \multirow{2}{*}{ Sig. } & \multicolumn{3}{|c|}{ Correlations } & \multicolumn{2}{|c|}{$\begin{array}{l}\text { Collinearity } \\
\text { Statistics }\end{array}$} \\
\hline & B & $\begin{array}{l}\text { Std. } \\
\text { Error }\end{array}$ & & & & $\begin{array}{l}\text { Zero- } \\
\text { order }\end{array}$ & Partial & Part & Tolerance & VIF \\
\hline 1 (Constant) & -.295 & .125 & & -2.348 & .020 & & & & & \\
\hline store layout & .415 & . 044 & .411 & 9.325 & .000 & .852 & .611 & .270 & .431 & 2.318 \\
\hline interior display & . 284 & . 048 & 263 & 5.944 & .000 & .810 & .441 & .172 & .427 & 2.344 \\
\hline human variable & .355 & .041 & .375 & 8.636 & .000 & .838 & .581 & .250 & . 444 & 2.251 \\
\hline
\end{tabular}

a. Dependent Variable: customer shopping orientation

Karena nilai t dari ketiga variabel $(9,325 ; 5,944$ dan 8,636) lebih besar dari $t_{\text {tabel }}(1,976)$ dengan signifikansi sebesar 0,000 , maka secara parsial dan signifikan store layout, interior display dan human variable berpengaruh terhadap customer shopping orientation. Dengan demikian hipotesis kedua juga terbukti.

Dari ketiga variabel yang ada, terlihat nilai koefisien beta yang paling besar adalah nilai store layout yaitu 0,415 (lebih besar dibandingkan dua variabel yang lain), maka hipotesis ketiga yang menyatakan bahwa store layout adalah variabel yang paling dominan mempengaruhi customer shopping orientation dapat diterima.

Hasil analisis menunjukkan bahwa store layout $\left(\mathrm{X}_{1}\right)$, interior display $\left(\mathrm{X}_{2}\right)$ dan human variable $\left(\mathrm{X}_{3}\right)$ mempengaruhi customer shopping orientation pelanggan restoran Dewandaru. Dalam hal ini dapat dikatakan bahwa pelanggan memutuskan pembelian karena restoran Dewandaru menawarkan suasana yang menarik bagi pelanggan. Ini dapat dilihat dari penggabungan antara tata ruang restoran yang luas dan nyaman. Dengan penempatan tata ruang yang luas dan menarik, restoran Dewandaru memberikan rasa nyaman bagi pelanggan untuk menikmati suasana dalam memenuhi kebutuhan mereka akan makanan dan minuman. Di samping itu dengan ruangan luas, restoran Dewandaru dapat menyediakan tempat sesuai dengan kebutuhan yang diinginkan oleh pelanggan. Pelanggan dengan orientasi belanja yang mengarah pada rekreasi akan lebih menyukai restoran yang mengutamakan kenyamanan karena sambil menikmati makanan dan minuman pelanggan juga dapat merasakan suasana budaya tradisional (adanya bangku dan kursi jati antik) dengan alunan musik tradisional yang mendukung. Ini mendukungg konsep restoran Dewandaru sebagai culture restaurant. Levy dan Weitz (2001) menyatakan bahwa store layout harus konsisten dengan citra store dan strategi perusahaan secara keseluruhan karena ini juga menentukan pelanggan dalam pengambilan keputusan pembelian.

Hasil analisis juga menunjukkan interior display berpengaruh secara positif terhadap customer shopping orientation. Saat ini, tujuan seseorang untuk mengunjungi sebuah restoran bukan hanya untuk memenuhi kebutuhan akan makanan dan minuman saja. Pelanggan mendatangi restoran sebagai sarana hiburan, berkumpul bersama keluarga ataupun relasi, dan juga bahkan sebagai sarana melepas stress. Dengan keunikan penataan interior yang dimiliki oleh Dewandaru, pelanggan akan merasakan suasana budaya yang kental begitu memasuki restoran ini. Joglo, patung dewa-dewi, serta beragam koleksi benda seni yang bernilai historis tinggi akan menyambut kehadiran pelanggan. Semakin ke dalam, pelanggan akan semakin merasakan perpaduan budaya yang begitu menarik dengan adanya bangunan utama restoran yang menyerupai rumah Tionghoa pada abad 18. Demikian juga dengan penggunaan perabotan-perabotan antik bernuansa tradisional yang semakin menunjukkan keunikan dari restoran Dewandaru.

Selain itu buku menu restoran Dewandaru didesain sedemikian rupa dengan nama-nama menu yang menarik dan unik juga mampu menarik keingintahuan pelanggan untuk menikmati menu makanan dan minuman yang dimaksud. Ini sejalan 
dengan apa yang disampaikan oleh Turley dan Milliman (2000) yang menyatakan interior display yang baik secara signifikan dapat memiliki efek pada pelanggan untuk melakukan pembelian. Lebih lanjut Ma'ruf (2006) juga sependapat bahwa keinginan untuk melakukan pembelian dapat diciptakan melalui interior display yang menarik. Interior display yang menonjol secara signifikan dapat mempengaruhi penjualan. Strategi diferensiasi ini ditujukan agar pelanggan mengunjungi restoran untuk melakukan pembelian berulang.

Lebih lanjut hasil analisis juga menunjukkan human variable berpengaruh secara positif terhadap customer shopping orientation pelanggan restoran Dewandaru. Ini menunjukkan bahwa human variable yang dalam hal ini merupakan bagian dari tingkat layanan karyawan restoran dapat digunakan supaya pelanggan dengan tingkat belanja yang tinggi akan merasa betah di restoran. Berlama-lama di restoran akan menciptakan kesan bahwa restoran yang banyak dikunjungi oleh pelanggan memiliki pencitraan sebagai restoran yang baik. Sebagai contoh, pelanggan dengan orientasi belanja rekreasi akan merasa tidak nyaman jika terus diikuti oleh pelayan restoran dalam hal memilih makanan. Namun jika dalam restoran tersebut kekurangan karyawan yang melayani, maka pelanggan juga akan malas untuk melakukan pembelian. Orientasi belanja pelanggan yang seperti ini membuat restoran harus mampu menempatkan karyawan dengan tepat untuk menyampaikan layanan yang baik bagi pelanggan yang datang. Tidak semua pelanggan datang hanya untuk rekreasi, namun juga untuk memenuhi kebutuhannya untuk bersantai dan bersosialisasi.

Tingkat kepadatan pelanggan di restoran Dewandaru yang sesuai dapat membuat pelanggan memperoleh privasi yang tinggi tanpa terganggu oleh pelanggan yang lain. Human variable ini dapat mempengaruhi keputusan pembelian dan kepuasan pelanggan. Hal ini senada dengan apa yang disampaikan oleh Bateson dan Hui (Turley \& Milliman, 2000). Menurut mereka, beberapa pelanggan tidak menyukai dampak modulasi lingkungan negatif yang terkait dengan kepadatan pelanggan (misalnya kondisi restoran terlalu ramai pengunjung dan sangat padat). Mereka juga menemukan bahwa strategi adaptasi pelanggan pada tingkat kepadatan di suatu tempat berpengaruh tinggi pada kepuasan belanja.

Dengan adanya ketiga faktor tersebut, pelanggan mendapatkan suasana yang nyaman dan berbeda dibanding restoran lainnya. Hal ini akan menyebabkan pelanggan untuk terus datang dan tertarik untuk melakukan pembelian di restoran Dewandaru. Restoran yang memiliki store layout, interior display dan human variable yang baik dapat memenuhi kebutuhan pelanggan sehingga hal ini akan tertanam dalam benak pelanggan ketika pelanggan akan melakukan pembelian ulang.

\section{SIMPULAN DAN SARAN}

Berdasarkan hasil analisis dan pembahasan maka dapat diambil simpulan sebagai berikut: Store layout, interior display dan human variable berpengaruh secara serempak dan signifikan terhadap customer shopping orientation pada restoran Dewandaru di Surabaya. Hal ini disebabkan semakin baik store layout, interior display dan human variable, maka customer shopping orientation juga akan baik. Jadi, hipotesis pertama dalam penelitian ini yang berbunyi "Store layout, interior display dan human variable berpengaruh secara serempak terhadap customer shopping orientation pada restoran Dewandaru di Surabaya" dapat diterima.

Store layout, interior display dan human variable berpengaruh secara parsial terhadap customer shopping orientation pada restoran Dewandaru di Surabaya. Hal ini disebabkan semakin baik secara parsial store layout, interior display dan human variable maka customer shopping orientation juga akan baik. Jadi, hipotesis kedua dalam penelitian ini yang berbunyi "Store layout, interior display dan human variable berpengaruh secara parsial terhadap customer shopping orientation pada restoran Dewandaru di Surabaya" dapat diterima.

Store layout berpengaruh paling dominan terhadap customer shopping orientation pada restoran Dewandaru di Surabaya. Hal ini disebabkan semakin baik store layout, maka customer shopping orientation juga akan baik. Jadi, hipotesis ketiga dalam penelitian ini yang berbunyi "store layout berpengaruh paling dominan terhadap customer shopping orientation pada restoran Dewandaru di Surabaya" dapat diterima.

Berdasarkan hasil simpulan yang didapat, maka saran yang dapat disampaikan kepada pihak manajemen restoran Dewandaru adalah sebagai berikut: Sebagai hal yang paling berpengaruh, store layout dari restoran Dewandaru harus tetap dipertahankan. Apabila memungkinkan, dikembangkan dengan sesekali merubah tata letak dari area pelanggan untuk menciptakan suasana baru bagi pelanggan serta mencegah timbulnya rasa jenuh dari pelanggan. Misalnya: sesekali merubah tata letak meja kursi di taman/ area outdoor atau tata letak meja kursi di bagian indoor.

Interior display merupakan salah satu faktor yang berpengaruh cukup kuat terhadap customer shopping 
orientation pada pelanggan restoran Dewandaru. Oleh karena itu pihak Dewandaru harus menjaga perabotan-perabotan yang digunakan agar selalu dalam kondisi yang baik. Misalnya dengan melakukan perawatan serta pembersihan secara berkala terhadap perabotan-perabotan tersebut (misalnya: meja, kursi, patung, dll).

Demikian juga dengan human variable yang juga turut memiliki pengaruh yang kuat terhadap customer shopping orientation. Hal ini dapat terus dipertahankan dan bahkan dikembangkan lebih baik lagi. Misalnya dengan mengadakan pelatihan secara berkala bagi para karyawan untuk meningkatkan tingkat pelayanan yang diberikan kepada tamu.

Untuk penelitian selanjutnya, selain ketiga faktor di atas peneliti dapat mengembangkan faktor-faktor lain yang mempengaruhi keputusan pembelian pelanggan di restoran, misalnya meneliti kualitas produk dan inovasi produk restoran Dewandaru. Pelanggan yang datang ke restoran sangat mengutamakan kualitas produk di samping ketiga faktor di atas.

\section{DAFTAR REFERENSI}

Ghozali, I. 2005. Aplikasi Analisis Multivariate Dengan Program SPSS, Semarang: Badan Penerbit Universitas Diponegoro.

Levy \& Weitz. 2001. Retailing Management. New York: McGraw Hill.

Ma'ruf, H. 2006. Pemasaran Ritel. Jakarta: PT. Gramedia Pustaka Utama.

Nonto, A. W. 2006. You are What You Invest. Majalah Pengusaha, Mei, 2006. edisi 60.

Sari, E.T. 2005. Peranan Consumer Value Dalam Mempertahankan Keunggulan Bersaing Pada Restoranran Cepat Saji. Jurnal Manajemen Perhotelan, 2(2).

Turley, L. W. \& Milliman, R. E. 2000. Atmospheric Effects On Shopping Behavior: A Review Of The Experimental Evidence. Journal of Business Research, 49: 193-211.

Sugiyono. 2007. Metode Penelitian Pendidikan: Pendekatan Kuantitatif, Kualitatif dan $R \& D$. Jakarta: Gramedia Pustaka Utama. 